\title{
Local Self-Governments and the Vertical Division of Power
}

\author{
Ádám Varga ${ }^{*}$ \\ * Assistant professor, Pázmány Péter Catholic University; Junior Assistant Professor, University of \\ Public Service, e-mail: varga.adam@jak.ppke.hu
}

\begin{abstract}
Local self-governments cannot be defined as entities against the state, nor do they merely assist in executing the central will. The significance of local self-governments lies in their role in the division and balancing of powers. In light of the principle of subsidiarity, the need for autonomy through decentralisation necessarily leads to the central bodies of the state being marginalised in these matters, in a sense, the latter lose their ability to solve the issues raised within their own sphere of competence.

From a certain point of view, this can even be considered a vertical division of power. The division of executive power between the public administration subordinated to the Government and independent local self-governments, does not call into question the local self-government's affiliation with the executive power. As such, it is practically an internal division of powers. In essence, it manifests itself as a kind of limited autonomy, which - due to the unity of the state - subsists only within the confines of the relevant laws.

In light of the foregoing, jointly applied principles lead to a vertical division of power. Power is divided, which, nonetheless, does not mean that one sovereign body limits another; it is rather the case of the state restraining itself by virtue of the principle of democracy.
\end{abstract}

Keywords: right to local self-government, vertical division of power, separated branch of power, protected powers

\section{Opening remarks}

According to the classical approach, the concept of municipal power was first introduced by Benjamin Constant, who added the requirement of vertical division of powers and decentralisation to the horizontal division of powers used so far (Csalló, 2014, p. 25). Today, the dominant model for the territorial division of powers in modern democratic state systems is that of self-government. As Ilona Pálné Kovács points out, there are essentially historical reasons for this since, in many countries, they were established before the central state institutional system and their collective nature was carried over into the unifying state organisation (Pálné Kovács, 2008, p. 13). Today, therefore, local self-government is a basic institution in all democratic states, but despite (or rather because of ) this, the precise definition of local self-governance and local self-government 
has been a century-old challenge for researchers. The main reason for this is that the idea of local self-governance is based on different foundations in different countries, and the paths of development are very different, too. István Ereky forthrightly argued that there are irreconcilable conflicts between the myriad theories of self-government (Ereky, 1932, p. 3). Of course, there are common basics, but there have been many differences in the details until recent times.

Local self-governments are in a vertical position compared to the classical actors in the division of powers. Opinions are divided among researchers on how to interpret this vertical position. Some argue that local self-governments must be seen as a separate branch of power. Others deny this and try instead to explain the situation of local selfgovernments by the vertical division of powers. Still others, however, argue that vertical division of powers can only be discussed in federal states, so it is meaningless in a unitary state. These authors typically see local self-government as a kind of restriction on the executive branch, or not even that.

However, looking at the individual constitutions, the situation is not clear either. Vertical division of powers is of course present in federal states, but there are also examples that focus explicitly on the role of local self-government: The Estonian Constitution treats local self-government as a separate branch of power, ${ }^{1}$ and the Croatian Constitution formulates the right to local self-government as a limitation of the three branches of power. ${ }^{2}$ Typically, however, the role of local self-governments in the division of powers can only be inferred from the interpretation of individual rules.

\section{Local self-government and division of powers}

When looking for the place of local self-governments in the system of branches of power, the primary question is on what basis we consider a branch of power to be a branch of power. Starting from the classical theories of John Locke and Montesquieu, and extending them in various ways, to the denial of the division of powers, ${ }^{3}$ the theories on this subject are almost endless. A detailed examination of all this is not the subject of the present paper. By considering the existence of the division of powers as a constitutional fact, ${ }^{4}$ I will only concentrate on how local self-governments can be placed in this system.

The division of powers is not about rigid separation but about mutual checks and balances (Fogarasi, Ivancsics \& Kiss, 1994, p. 21). From an organisational point of view, any body performing a task of public authority can be seen as a separated branch of power, which is not dependent on other actors but limits their power. This makes the

\footnotetext{
Constitution of the Republic of Estonia, Article 14.

Constitution of the Republic of Croatia, Article 4.

Benjamin Constant, for example, considered the division (separation) of powers as futile, because if the amount of power is infinite then the actors need only to form a coalition to tyrannise. The key is to ensure that no actor oversteps its authority (Constant, 1997, p. 81).

4 In this respect, I also rely on Article C(1) of the Fundamental Law of Hungary, according to which the functioning of the Hungarian State shall be based on the principle of the division of powers.
} 
list quite long, and it is clear that this approach also has a centuries-old tradition. ${ }^{5}$ If, on the other hand, the branches of power are distinguished functionally, according to the type of task they perform, there is no reason to extend the classical triad. This does not, of course, exclude the possibility of several bodies sharing the responsibilities of one branch of power. Hence, with their autonomy, each actor of power may limit each other within a given branch of power, but each is the custodian of the realisation of a given type of task.

The challenges of our modern world make it less and less possible to follow a particularly rigid, institutional division. The proliferation of different bodies increasingly implies an increase in the complexity of the tasks they perform, ${ }^{6}$ while it is difficult to deny that the activity they perform still falls within one of the three functions of state power (perhaps explicitly mixed). For this reason I can easily agree with András Zs. Varga, who suggests a functional approach to the division of powers instead of an institutional one, and sees a need to break with the one power - one organisation approach. No single branch of power can be tied to a single exclusive body, and an organisation does not typically exercise only one kind of power (Varga, 2019, pp. 37-38).

This raises the question of whether local self-governments can be considered a separate branch of power. The emergence of municipal power in legal literature is usually associated with the work of Constant. It is true that, according to him:

Until now, local government has been regarded as a dependent branch of the executive; on the contrary, it must never be an obstacle to it, but it should not be dependent on it either. If the interests of the parts and of the whole country are entrusted to the same hands, or if the local interests are made to be represented by depositaries, there will be many evils, and even those evils which seem to be mutually exclusive will coexist (Constant, 1862, p. 126). ${ }^{7}$

Constant is said by many to have added local self-government to the triad of the branches of power, but I see this as an oversimplification. His theory suggests, first of all, that local self-governments are in a vertical position in relation to the central executive power, and that they have protected functions; that is, the principles of subsidiarity and autonomy actually make local governments the counterbalance of power. János Sári also interprets Constant's theory in such a way that he does not speak of a separate branch of power but only of a division based on locality, which presupposes self-interest (Sári, 2007, p. 42). Ereky draws attention to its practical application, reporting that in Belgium, to counteract the extreme centralisation, the constitution recognised county or municipal power as the fourth branch of power in addition to those named by Montesquieu. In principle, many authors have tried to base the French model of decentralisation on this, but in reality, they have developed and codified the principles of the French system of modern local self-government (Ereky, 1939, p. 192). What is

\footnotetext{
Moreover, the extension of the division of powers to dimensions that are not or not necessarily linked to the exercise of public power is not new (Erdős \& Smuk, 2017, p. 139).

6 Examples include the activities of the Court of Auditors or the Ombudsman of Hungary.

It can be read in French in the 'new' edition of the Cours de politique constitutionnelle, ed. by Jean-Pierre Pagès, Paris, Didier, 1836, vol. I, 151.
} 
certain is that, in the wake of Constant's theory, questions about the local selfgovernment being an autonomous, separate branch of power have popped up again and again in the legal literature, but for a long time they have not really managed to take root. Zoltán Magyary, for example, considered it a matter settled by science that local self-government is a simple form of executive power, in which, however, the nation is not only involved in the exercise of executive power through parliamentarism prevailing in the sphere of legislative power but also directly complementing and, together with the representation of the people, constituting full constitutionalism. However, according to him, local self-government is necessarily and exclusively a state executive function, in which the members of the nation, in the service of the state, carry out the will of the state on themselves (Magyary, 1930, p. 166).

It was only in the second half of the twentieth century that the neoliberal development of the state began to go back to Constant's principle and the natural law origins of local self-government, and with it the classification of local self-government as a separate branch of state power. According to István Balázs, these are ideas that absolutise the democratic nature and autonomy of local self-governments, which reached their peak in the decentralisation reforms and regionalisation of the 1980s (Balázs, 2014, p. 298). Zsuzsanna Árva also stresses that the classical Montesquieuian concept of separation of powers is hardly applicable in the modern era. According to her, there are several factors (their status separate from the state administration, their autonomy) related to local selfgovernments established based on the principle of decentralisation, which raise the question of recognition as a factor of power (Ârva, 2014, pp. 37-38). According to the view labelled conservative by Balázs, local self-governments performing executive branch functions have the character of being a separate branch of power because of their autonomy while, according to the other view, in addition to executive functions, they also perform the territorial division of state power, and therefore they effectively function as a separate branch of power. The difference is more theoretical, manifested in the relationship with state bodies, since, if local self-government functions as a separate branch of power, it has looser links to central state bodies and looser control by the Government. The practical relevance of this issue was greater in the case of the newer democracies that emerged from dictatorships (the more radically independent branch of power characteristic emerged as a counter-effect), but the global economic crisis has also forced a reassessment of their role in these states (Balázs, 2014, pp. 298-299).

The perception of them as a separate branch of power is therefore dynamically changing in both time and space, ${ }^{8}$ and, in my view, the significance of the question in this form is negligible. While there are some authors who posit local self-governments as a separate branch of power, many focus more explicitly on vertical division of powers (e.g. Veress, 2005, p. 260), whereas others focus more on the exercise of autonomy (e.g. Ivancsics, 1996, p. 185) or the realisation of a counterbalance of power (e.g. Berényi, 2003, p. 309) from a practical perspective.

According to Péter Szegvári, for example, local self-governments could be considered to be a separate branch of power under the Constitution rather than under the system of the Fundamental Law (Szegvári, 2017, p. 763). 
In my view, local self-governments do not perform a different type of function compared to the other branches of power (they are close to the executive power, but they are also representative and autonomous in their rule-making; see Csink, 2014, p. 155); they just do it on a different level. Their position cannot therefore be understood in a system of division of powers created based on a horizontal logic, and their relations with other actors can only be understood vertically.

\section{Federation versus local self-government, vertical division (separation) of powers in the narrow sense}

In the light of the above, the possibility arises that the conceptual ambiguity could be resolved through the principle of vertical division of powers. However, this also presents a number of difficulties. The vertical division of powers is generally based on the principle that the exercise of power can be subdivided into certain territorial or corporate levels. The principle of division of powers is also implemented by the division of state power into central, regional or local levels or autonomous bodies (Petrétei, 2018, p. 30). Vertical division (in the original sense: separation) of powers is a product of American legal doctrine. In the broadest sense, it prevails when the decision-making freedom of one body is limited, or at least counterbalanced, by another body organised on a different territorial basis (Csink, 2014, p. 156).

In federal states, the powers of the federal parliament are limited to regulating matters at the federal level, while the powers of the member states enjoy strict constitutional protection (Erdős \& Smuk, 2017, p. 138). In these states, both the member state level and the federal level have the attributes of statehood and the member states join the federation in possession of their sovereignty. As they retain their sovereignty within the federal state, it is necessary to settle which powers belong to the federation and which to the member state. This inevitably leads to a vertical division (separation) of powers, where sovereign constrains sovereign. It should also be noted, however that, in Hans Kelsen's interpretation for example, the essence of the federal state is the degree and type of decentralisation, which requires a specific constitutional premise. In this, he did not consider the method of formation and the existence of sovereignty (whether only the central state, only the member state, or both are sovereign) to be important; he considered it a pseudo-problem (Kelsen, 1927, pp. 59-60).

In contrast, in unitary states, local self-governments do not have any rights - in a public law sense - to counterbalance legislative power, but the right of local communities to self-government must be respected by the state (Szoboszlai, 2011, p. 29). In addition, however, the legislative powers of the Parliament in these states are very broad, leaving it to the political discretion of the national assembly to distinguish between local and national matters (Erdös \& Smuk, 2017, p. 138). Local self-governments are not mini-republics, but an integral part of the state mechanism, from which, however, the powers granted to them by law make them relatively separate and autonomous (Fogarasi, Ivancsics \& Kiss, 1994, p. 21). 
While in a federation, the sovereignty of the member states remains intact in matters that do not fall under federal competence; the local self-governments in a unitary state (or within a member state of a federal state) may influence the central power, but they are always subject to the authority of the central power (Dezsö \& Somody, 2007, pp. 148-149). This means that the vertical division of powers achieved by the federal system is not in itself guaranteed. ${ }^{9}$ At the same time, the presence of local self-governments results in an internal division of executive power, and therefore the local autonomy that is achieved plays a power-limiting role (Veress, 2005, p. 275). Magyary, for example, did not agree with this restrictive role. He divided the types so that the local self-government, in terms of its substance, can be political and administrative. Of these, political local self-government also has legislative power, so it does not maintain the unity of state law. He (also) identified this with federalism. In the other system, they maintain the unity of state law, but their administrative powers are not complete. The public power is centralised with the central government, so if the local self-government exercises a public power, it can only exercise it within the powers delegated and delimited by the state and not by original right and at will. Local self-government is, in his view, just a specific form of state administration (Magyary, 1942, p. 113). Ereky (1939, p. 193) presented a very similar French view on the same issue, with the difference that, in his opinion, the French do not recognise the distinction between administrative decentralisation and constitutional decentralisation (they only distinguish between federalisation and decentralisation).

It should also be stressed that in recent times, in an increasing number of countries, units that were previously considered to be of a local self-government nature have become similar to a member state, thus making differentiation relative (Hoffman, 2015, pp. 43-44). In regional states, regions have more extensive powers than local selfgovernments (for instance, they can have their own government), but their sovereignty is not recognised. Csaba Erdős and Péter Smuk argue that, in these states, the autonomous territory's independent share of the supreme power is not recognised, but its independent right to regulate is, and its exercise is possible even through the parliament, i.e. territorial autonomy is seen as a constitutional limitation of the central parliament (Erdős \& Smuk, 2017, p. 138).

Kelsen's approach shows the relativity of demarcation and the possibility of transition quite well. He argues that the extension of local self-government decentralisation towards general norms (which usually implies a relatively larger spatial scope for local norms) creates a 'land' (country)-based decentralisation, whereby executive power, as well as legislative power, are shared between central and local bodies. It is difficult to distinguish these 'countries' from autonomous provinces, especially if the provinces can also pass autonomous statutes (possibly provincial laws) and if the bodies of the 'countries' are democratic as well. The only difference in this case is the greater legislative power, and from there - with increased decentralisation (which means constitutional

\footnotetext{
Consequently, according to László Sólyom, the Hungarian Constitutional Court has never considered municipal autonomy as a quasi-federal structure. Only an ex-post examination of a local self-government decree for overstepping legislative power can be considered a hidden, quasi-federal review of powers (Sólyom, 2001, p. 769).
} 
powers ) - it is only a step to becoming a member state of the federal state. In any case, the member state also benefits from central legislative and executive powers through the Second Chamber of the Parliament (Kelsen, 1927, pp. 58-59).

On the basis of the above, it can be stated that only the system of federal states can be considered to have vertical division (separation) of powers in the literal sense of the word, and that this concept cannot be interpreted to mean the system of local selfgovernments within unitary states (or within a member state of a federal state). ${ }^{10}$

\section{Vertical division of powers as an outcome}

Many scholars go no further than the above approach, considering vertical division of powers a feature of the federal state structure, which essentially requires sovereignty to be limited by another sovereign. These approaches are very logical, but also very formal. I do not consider it inherently unacceptable to call the principle of federalism a vertical division of powers; however, I must also stress that, on the one hand, it is unfortunate to consider it the only vertical limit to power, and, on the other hand, it is not a view to be dismissed that everything which ultimately limits the exclusivity of central state power from a functional point of view can be considered a vertical division of powers.

The balance ensured by the division of powers (the essence of which, as stated above, is the mutual checks and balances) must also be reflected in the relationship between central and local power. The balance of power must also be present and characteristic of the vertical division of labour (Fogarasi, Ivancsics \& Kiss, 1994, p. 21). In Péter Szegvári's approach, the fundamental rights and competences of local self-governments (following István Bibó's line of thought) technically enable the disruption of the concentration of power, as well as the establishment of vertical division of powers and the emergence of power competition (Szegvári, 2017, p. 765). Antal Ádám highlights that, in the constitutional definition of fundamental powers and in the legislation respecting them, there is a transfer of certain public powers, which he also calls vertical division of powers (Ádám, 2000, pp. 151-152). By vertical division of powers, Emőd Veress means the division of powers between the central state and the local self-government, within the executive (Veress, 2005, p. 294). Herbert Küpper also uses the term

\footnotetext{
${ }^{10}$ Lóránt Csink himself argues in favour of the above interpretation of vertical division of powers, but he also adds popular sovereignty to this and emphasises that, in a narrower sense, the legitimacy of the two institutions must be identical for the vertical division of powers to be realised, i.e. both must be the bearers of popular sovereignty. Consistent with other authors, he argues that, in federal states, both the member state and the federation have sovereignty, but in the unitary state there is no entity that also has sovereignty besides the central power. However, he also argues that if the people as a whole are the source of sovereignty, sections of the people are not. Obviously, the power of the state derives from the people and can be explained dogmatically, but linking state sovereignty and popular sovereignty so directly is rather problematic from a practical point of view. Csink himself uses this reasoning, which I think is the main argument against this approach. Namely that several federal states designate the people as a whole as sovereign. As far as Hungary is concerned, he resolves this by saying that vertical division of powers is not realised because local self-governments are not given sufficient powers and guarantees. This explanation, however, ultimately argues against rather than supports the direct link between popular sovereignty and vertical division of powers. But it is precisely for this reason that I myself attach importance to the role of popular sovereignty (Csink, 2014, pp. 156-157).
} 
vertical division of powers to describe the division of power within the executive. The division of executive power to state administration that is subordinate to the Government and to autonomous local self-governments is a vertical division of powers, but it does not call into question that local self-government belongs to the executive power. It is, in effect, an internal division of powers, he says, with checks and balances, because, in practical terms, it is the executive that poses the greatest threat to individual freedom. He also mentions that the Constitutional Court essentially calls this autonomy (Küpper, 2009, pp. 1503-1504). In the context of checks and balances, Pálné Kovács argues that the American constitutional tradition also sees local self-governments as checks vis-à-vis the central state and the dictatorship of the majority. He therefore does not reject a constitutional solution based on the territorial division of power (Pálné Kovács, 1996, p. 132).

I believe that, if local power and central power respect each other's latitude, it necessarily leads to a vertical division of power. Not because there are duplicated levels of power, but precisely because there are not. Local self-governments clearly do not have state sovereignty and should not be seen as the central power's 'competitors'. On the contrary, both are acting in their own capacity. The state does not want to take over the affairs of local communities, while local self-governments do not want to be the state within the state. In this reading, this principle is mostly about self-limitation, which in turn leads to an ultimate division of power between the central and local levels. It is more a result than a starting point, and therefore could not be further from the principle of what we call vertical division of powers in the case of federal states. Yet the result is similar: The state does not interfere in local affairs and vice versa, i.e. the principles of autonomy and subsidiarity apply. In Reinhard Hendler's formulation, local self-government as an instrument of decentralisation leads to a plurality of state decision-makers, and serves to dismantle political power as an actor in the vertical division of powers (Hendler, 2007, p. 15). This division can be assessed primarily against the central executive power, but the legislative power must also respect the limits set by the constitutional power, such as the right to adopt regulations on local public affairs. The legislative is thus also limited, in that it cannot by law empty the powers of the local self-governments.

This derivation is obviously close to what can typically be included in the concept of autonomy. However, while autonomy provides an answer to the question of what the state decides that local self-governments have the right to do, the vertical division of powers is more helpful in answering why the possibility of state intervention in the implementation of autonomy needs in fact to be limited.

It must be readily acknowledged that, precisely because of the above arguments, it is perhaps unfortunate to call this principle vertical division of powers, as it can easily give rise to misunderstandings. I am convinced, however, that the emphasis should not be on the designation but on whether local self-government is ultimately capable of counterbalancing and limiting central state power. Therefore, in contrast to the classical approach of vertical division of powers, it is not the theoretical framework but rather the practical effects that I consider to be decisive. In agreement with Veress, two prerequisites must be highlighted for this to be feasible: On the one hand, the division of 
central and local self-powers and, on the other, the possibility for local communities to have a different political choice (Veress, 2005, p. 275). This is what enables the local self-government to have the opportunity to make decisions within the limits of the law, based on its own interests, and different from the intentions of the central state power. However, to guarantee this, it is also essential that the freedom of local self-governments to do so is guaranteed by law and by the courts, as well. Jenö Kaltenbach highlights in particular that the autonomy of local self-government must be protected, even against legislation that is aimed at national political interests (so that the autonomy of local selfgovernment cannot be abolished or fundamentally changed by a simple law), and at the same time, like the horizontal elements, local self-government must be subject to regulation by the constitution (Kaltenbach, 1991, pp. 136-137).

\section{A summary of the process of vertical division of power}

In light of the previous point, I will attempt to sketch in a nutshell how and why the interplay of the various principles of local self-government can lead to a vertical division of power. The scope of this paper does not allow for a detailed elaboration, but I will try to illustrate the main points.

My starting point is that local self-governments cannot be defined in opposition to the state, nor are they simply technical assistants to the state. The importance of local self-government lies rather in its power-sharing and power-balancing character (Stern, 1981, p. 204). Originally developed in many countries in opposition to absolutist state power, in a globalising world it is no longer possible to understand local self-government in its original sense, as all parts of the state are now democratically constructed (Hoffmann-Axthelm, 2004, pp. 13-14). In a parliamentary democracy, it is no longer the people against state power, but only the whole people against their own parts. On this basis, the importance of defending self-governance arises when the views of smaller communities need to be defended against the whole of the state, which holds all the power (Peters, 1926, p. 43).

Autonomy is one of the most important characteristics of local self-governance. Although autonomy and self-governance are commonly thought of as synonymous concepts, autonomy in relation to public institutions is really about self-regulation based on legal authority (Hendler, 2007, p. 12). Autonomy is therefore the right of a community other than a state to create law for itself (Peters, 1926, pp. 37-38). Necessarily limited, autonomy does not protect action that does not comply with the legal framework. As the autonomous body is part of a larger political system, the principle of autonomy must be reconciled with the principle of unity (Ladner et al., 2019, pp. 175-176).

The principle of subsidiarity makes it a natural requirement to seek local solutions to local problems. Even without a mention in the constitution, this principle is considered one of the most important principles (Knemeyer, 1990, p. 174). It prohibits unwarranted interference by higher levels of power in the sphere of competence of lower levels, i.e. interference that is incompatible with the common good (Frivaldszky, 2006, 
p. 36), and specifies that the higher level may intervene in the relations of the lower level only in order to help it. However, this does not mean that these cases cease to be national cases. The local community may want to be given an appropriate degree of freedom and autonomy to manage and solve its own affairs. The subsidiarity principle both defines and limits freedom of action. Indeed, the legitimate authority is empowered to replace a failing actor if necessary (Berthet \& Cuntigh, 2006, p. 186). This is why, in some cases, it is part of the subsidiarity principle to move certain tasks that are insoluble at a lower level to a higher level (Waschkuhn, 1995, p. 59). The European Charter of Local SelfGovernment also states that, ${ }^{11}$ in general, public tasks need to be carried out primarily by the administrative body closest to the citizen. The delegation of tasks to another administrative body must depend on the nature and size of the task and on efficiency and economic requirements. ${ }^{12}$

Even so, this does not mean that the municipalities have sovereign power; in fact, it must depend on the wise discretion of the state to delegate the tasks. The way to achieve this is decentralisation, which is not only a practical principle of administrative organisation, but also a building block of local self-government (Soós, 2010, p. 57). If, on the basis of subsidiarity, the need for autonomy is asserted through decentralisation, this inevitably leads to the central bodies of the state being marginalised in relation to the issues involved and, in a sense, losing the possibility of solving the problems that arise under their own authority.

In some respects, this can even be called vertical division of powers, because in the constitutional definition of fundamental powers and in the legislation respecting them, there is a transfer of certain public powers (Ádám, 2000, pp. 151-152), which also serves to dismantle political power (Hendler, 2007, p. 15). However, apportioning executive power to state administration, which is subordinate to the government, and to autonomous local self-governments, does not call into question that local self-government belongs to the executive power. It is effectively an internal division of powers (Küpper, 2009, pp. 1503-1504). In terms of its outcome, it essentially manifests itself as a kind of limited autonomy, which, however, due to the unity of the state, exists only within the framework of the law.

The real emphasis is on having things that can be done locally, independently and democratically. The aim, in my view, is to ensure that local communities carry out tasks that are truly local and can be carried out on their own (with the help of the central level), with a focus on the principle of subsidiarity. These are the local self-government's functions and powers. In light of the above, the combination of principles leads to a vertical division of power. Power is divided, nevertheless, it is not a sovereign entity limiting the other sovereign entity, but the sovereign state limits itself by virtue of the principle of democracy.

In principle, it is the sovereign decision of the state to recognise what is a local public matter, but this also imposes obligations on the state in the context of subsidiarity. This could be ensured through deconcentration as well, but, through

\footnotetext{
11 Convention on the European Charter of Local Self-Government, signed in Strasbourg on 15 October 1985.

12 Local Self-Government Charter, Article 4(3).
} 
decentralisation (thereby recognising autonomy), the central power necessarily limits itself, because it transfers powers to the local self-governments concerning which it cannot later claim to have the central executive power take over the decisions concerned. This leads to a situation where the central level of the state necessarily abdicates its right to decide on the issue. This, I am convinced, whatever the name, is effectively a vertical division of power.

\section{References}

Ádám, A. (2000). Az önkormányzati rendszer alkotmányi összefüggéseiről. In I. Verebélyi (Ed.), Egy évtized önkormányzati mérlege és a jövő kilátásai. MKI \& MTA PTI \& MTA RKK.

Árva, Zs. (2014). A helyi önkormányzás alkotmányos keretei, szervezeti rendszere, az önkormányzatok típusai Magyarországon. In I. Balázs (Ed.), Helyi önkormányzatok. Debreceni Egyetemi Kiadó.

Balázs, I. (2014). Új tendenciák a helyi önkormányzati rendszer szabályozásában Magyarországon és az Európai Unió tagországaiban. In I. Balázs (Ed.), Helyi önkormányzatok. Debreceni Egyetemi Kiadó.

Berényi, J. (2003). Az európai közigazgatási rendszerek intézményei. Rejtjel.

Berthet, T. \& Cuntigh, P. (2006). Local Mirrors of State Modernisation: The Case of the Territorialisation of Employment Policy in France. In V. Hoffmann-Martinot \& H. Wollmann (Eds.), State and Local Government Reforms in France and Germany. VS Verlag für Sozialwissenschaften. Online: https://doi. org/10.1007/978-3-531-90271-5_10

Constant, B. (1997). A régiek és a modernek szabadsága. Atlantisz.

Constant, B. (1862). Az alkotmányos politica tana. Trattner-Károlyi.

Constant, B. (1836). Cours de politique constitutionnelle, ed. by Jean-Pierre Pagès. Didier.

Csalló, K. (2014). Önkormányzás, autonómia. A helyi önkormányzatok szabályozási típusai Európában. In Cs. Feik, (Ed.), Magyarország helyi önkormányzatai. NKE KTK.

Csink, L. (2014). Mozaikok a hatalommegosztáshoz. Pázmány Press.

Dezső, M. \& Somody, B. (2007). A szuverenitás. In I. Kukorelli (Ed.), Alkotmánytan I. Alapfogalmak, alkotmányos intézmények. Osiris.

Ereky, I. (1932). Közigazgatási reform és a nagyvárosok önkormányzata. Budapest Székesföváros Házinyomdája.

Ereky, I. (1939). Közigazgatás és önkormányzat. Szeged Városi Nyomda és Könyvkiadó.

Erdős, Cs. \& Smuk, P. (2017). Parlament és hatalommegosztás. In P. Takács (Ed.), Unitas multiplex. Ünnepi tanulmányok Szigeti Péter 65. születésnapjára. Gondolat \& SZE DFK.

Fogarasi, J., Ivancsics, I. \& Kiss, L. (1994). A helyi önkormányzatok kézikönyve. Unió.

Frivaldszky, J. (2006). Szubszidiaritás és az európai identitás a közösségek Európájáért. In J. Frivaldszky (Ed.), Szubszidiaritás és szolidaritás az Európai Unióban. Faludi Ferenc Akadémia.

Hendler, R. (2007). Grundbegriffe der Selbstverwaltung. In T. Mann \& G. Püttner (Eds.), Handbuch der kommunalen Wissenschaft und Praxis. Band 1 Grundlagen und Kommunalverfassung. Dritte, völlig neu bearbeitete Auflage. Springer. Online: https://doi.org/10.1007/978-3-540-68884-6_1

Hoffman, I. (2015). Gondolatok a 21. századi önkormányzati jog fontosabb intézményeiről és modelljeiről. A nyugati demokráciák és Magyarország szabályozásainak, valamint azok változásainak tükrében. ELTE Eötvös.

Hoffmann-Axthelm, D. (2004). Lokale Selbstverwaltung - Möglichkeit und Grenzen direkter Demokratie. VS Verlag für Sozialwissenschaften. Online: https://doi.org/10.1007/978-3-322-81024-3

Ivancsics, I. (1996). A helyi és területi közigazgatás alkotmányi szabályozásának néhány alapkérdése és alternatívája. In I. Verebélyi (Ed.), A helyi önkormányzatok alkotmányi szabályozása. KJK - MTA ÁJTI.

Kaltenbach, J. (1991). Az önkormányzati felügyelet. Universum.

Kelsen, H. (1927). Az államelmélet alapvonalai. Szeged Városi Nyomda és Könyvkiadó. 
Knemeyer, F.-L. (1990). Subsidiarität - Föderalismus, Dezentralisation: Initiativen zu einem „Europa der Regionen“. Zeitschrift für Rechtspolitik, (5), 176-186.

Küpper, H. (2009). A helyi önkormányzás joga. In A. Jakab (Ed.), Az Alkotmány kommentárja II. Századvég.

Ladner, A., Keuffer, N., Baldersheim, H., Hlepas, N., Swianiewicz, P., Steyvers, K. \& Navarro, C. (2019). Patterns of Local Autonomy in Europe. Palgrave Macmillan. Online: https://doi.org/10.1007/978-3319-95642-8

Magyary, Z. (1930). A magyar közigazgatás racionalizálása. Királyi Magyar Egyetemi Nyomda.

Magyary, Z. (1942). Magyar közigazgatás - A közigazgatás szerepe a XX. sz. államában a magyar közigazgatás szervezete működése és jogi rendje. Királyi Magyar Egyetemi Nyomda.

Petrétei, J. (2018). Hatalommegosztás. In A. Jakab \& B. Fekete (Eds.), Internetes jogtudományi enciklopédia. Online: http://ijoten.hu/szocikk/alkotmanyjog-hatalommegosztas

Pálné Kovács, I. (1996). A helyi önkormányzatok alkotmányos szabályozása. In I. Verebélyi (Ed.), A helyi önkormányzatok alkotmányi szabályozása. KJK \& MTA ÁJTI.

Pálné Kovács, I. (2008). Helyi kormányzás Magyarországon. Dialóg Campus. Online: https://doi.org/10.17649/ TET.22.1.1152

Peters, H. (1926). Grenzen der kommunalen Selbstverwaltung in Preussen. Springer. Online: https://doi. org/10.1007/978-3-642-47664-8

Sári, J. (2007). A hatalommegosztás és a társadalmi-többségi elv. In I. Kukorelli (Ed.), Alkotmánytan I. Alapfogalmak, alkotmányos intézmények. Osiris.

Soós, E. (2010). A szubszidiaritás mint a többszintű kormányzás működését meghatározó alapelv. In P. Á. Ferwagner \& Z. Kalmár (Eds.), Távolabbra tekintve: tanulmányok J. Nagy László 65. születésnapjára. Universitas Szeged.

Sólyom, L. (2001). Az alkotmánybíráskodás kezdetei Magyarországon. Osiris.

Stern, K. (1981). Die Verfassungsgarantie der kommunalen Selbstverwaltung. In G. Püttner (Ed.), Handbuch der kommunalen Wissenschaft und Praxis. Band 1 Grundlagen. Zweite, völlig neu bearbeitete Auflage. Springer. Online: https://doi.org/10.1007/978-3-662-11967-9_14

Szegvári, P. (2017). A helyi önkormányzatok szerepváltozása a rendszerváltozás utáni alkotmányos rendszerben. In N. Chronowski, P. Smuk, Zs. Szabó \& Z. Szentmiklósy (Eds.), A szabadságszerető embernek. Liber Amicorum István Kukorelli. Gondolat.

Szoboszlai, Gy. (2011). Búcsú a jogállamtól. A hatalommegosztás modellje a 2011. évi alaptörvényben. Eszmélet, (2), 5-31.

Varga, Zs. A. (2019). From Ideal to Idol? The Concept of the Rule of Law. Dialóg Campus.

Veress, E. (2005). A hatalommegosztás aktualitása. Magyar Kisebbség, (3-4), 236-297.

Waschkuhn, A. (1995). Was ist Subsidiarität? Ein sozialphilosophisches Ordnungsprinzip: Von Thomas von Aquin bis zur "Civil Society”. Springer. Online: https://doi.org/10.1007/978-3-663-12443-6 